\title{
Danda Janda: Strategi Advokasi LSM PEKKA dalam Memberdayakan Perempuan Rentan di Desa Batangan Kabupaten Bangkalan ${ }^{1}$
}

\author{
Anastasia Imelda Cahyaningrum²
}

\begin{abstract}
Abstrak
Artikel ini membedah kaitan antara belenggu sistem patriarki bagi perempuan desa, terutama janda desa, dalam mengakses hak-hak politik dan ekonomi dengan strategi advokasi sebagai salah satu koridor pemberdayaan perempuan. Patriarki sebagai sebuah sistem telah menempatkan perempuan pada peran domestik-jauh dari bentuk-bentuk partisipasi politik di ruang publik-sekaligus peran reproduksi yang menyingkirkan perempuan dari akses sumber daya ekonomi. Meminjam kerangka konsep strategi advokasi dengan fokus pada aspek perubahan dan audiens, artikel ini mengeksplor program dan pendekatan LSM PEKKA dalam memberdayakan janda desa di Desa Batangan, Kabupaten Bangkalan. Hasil dari penelitian ini menunjukkan bahwa perlindungan sosial menjadi kebutuhan utama janda desa. Ketimbang sebatas persoalan administratif, perlindungan sosial menjadi basis material yang mampu membuka akses lebih luas terhadap ruangruang partisipasi publik dan sumber daya ekonomi. Pun demikian, upaya pemberian akses ini perlu memperhatikan jejaring aktor berpengaruh untuk kemudian mengupayakan perubahan dari strategi advokasi yang dirumuskan. Artikel ini menyimpulkan bahwa strategi advokasi efektif dilakukan dengan berfokus pada pemilihan isu, yang kemudian menjadi program utama PEKKA, dan pemetaan aktor lingkar kuasa Kepala Desa untuk jaringan kader awal.
\end{abstract}

Kata Kunci: Perempuan Kepala Keluarga; Perempuan Rentan; Perempuan Desa; Strategi Advokasi

1 Penelitian ini merupakan kerja sama Reseacrh Centre for Politics and Government (PolGov) dengan MAMPU dan Melbourne University dalam proyek penelitian Women Collective Action. Penelitian ini dilakukan di 10 desa di Indonesia selama Februari 2019 hingga September 2019.

2 Anastasia Imelda Cahyaningrum adalah peneliti junior di Reseacrh Centre for Politics and Government (PolGov), Fakultas Ilmu Sosial dan Ilmu Politik, Universitas Gadjah Mada. 


\section{PENDAHULUAN}

Persoalan perempuan rentan yang menjadi kepala keluarga ditunjukkan dengan angka perempuan kepala keluarga di pedesaan yang kian meningkat. Menurut Badan Pusat Statistik (2019), angka kepala rumah tangga perempuan di pedesaan yang bekerja mencapai angka 65,26\%. Angka ini menunjukkan persentase cukup jauh dari angka kepala rumah tangga laki-laki bekerja di pedesaan yang mencapai 94,6\%. Data BPS juga menunjukkan bahwa sejak tahun 1985 hingga 2019, terlihat konsistensi kenaikan rumah tangga yang dikepalai perempuan rata-rata sebesar $0,1 \%$ setiap tahunnya.

Para perempuan ini secara fungsional menjadi kepala keluarga karena suami meninggal dunia, bercerai, ditinggal, tidak atau belum menikah, suami berpoligami, suami merantau, suami sakit permanen, ataupun suami tidak bekerja (PEKKA\&SMERU, 2012). Padahal secara legal, keberadaan mereka tidak terjamin oleh Undang-Undang. Dalam konteks Indonesia, Undang-Undang Perkawinan Nomor 1 Tahun 1974 menegaskan bahwa kepala keluarga adalah suami atau laki-laki, dan hal ini tercermin dalam seluruh sistem sosial, ekonomi, dan politik yang berlaku. Sebagai akibatnya, perempuan tidak diakui sebagai kepala keluarga dan mendapatkan diskriminasi dalam kehidupan sosial politiknya (PEKKA, 2018). Selain itu, data PEKKA menunjukkan bahwa setidaknya $78 \%$ dari perempuan kepala keluarga dan janda mengalami perceraian karena kekerasan dalam rumah tangga, sedangkan hanya $41 \%$ dari mereka yang mencatatkan pernikahannya secara formal. Status janda dalam realitasnya, menambah kerentanan 
bagi perempuan desa, tidak saja secara sosial, tetapi juga secara ekonomi (wawancara bendahara PEKKA tanggal 4 Oktober 2019).

Persoalan semacam ini telah dibahas dari beberapa sudut pandang. Maria Mies (1986), dalam tulisannya mengenai housewifization, menjelaskan bahwa pemikiran kapitalistik Barat memiliki pengaruh terhadap persepsi perempuan sebagai ibu rumah tangga. Sementara posisi laki-laki diasosiasikan dengan istilah kepala keluarga atau pemimpin keluarga. Hal ini menempatkan perempuan sebagai pihak yang dependen terhadap pemasukan ekonomi laki-laki. Kapitalisme yang ditopang oleh patriarki memosisikan pekerjaan rumah tangga perempuan sebagai proses "tidak bekerja", dan diterjemahkan sebagai sebuah "pelayanan terhadap suatu tatanan keluarga". Mies berargumen bahwa proses "pengiburumahtanggaan" dipengaruhi oleh eksploitasi dari perkembangan kapitalisme dan studi-studi imperialis Barat yang menempatkan posisi perempuan, seperti layaknya masyarakat terjajah, berada di luar "masyarakat"-dalam tatanan masyarakat kapitalistik. Hal ini kemudian membuat perempuan mampu dieksploitasi secara gratis "seperti halnya air dan udara" (Mies, 1986).

Pun demikian, menyematkan praktik peminggiran sebatas pada sistem masyarakat kapitalistik agaknya ceroboh. Narasi the law of the father yang menempatkan laki-laki, terutama kepala keluarga, sebagai pemegang-dan pengelola-sumber daya juga hadir dalam konteks masyarakat pra-kapitalis, seperti ditulis dalam studi Murray (2005). Dalam sistem sosial feodalisme, misalnya, Murray menekankan pembagian peran gender tradisional yang menempatkan perempuan 
pada peran domestik. Hal ini menjauhkan perempuan dari akses atas urusan-urusan publik, termasuk partisipasi politik.

Secara lebih spesifik, perspektif lain melihat peran perempuan yang belum menunjukkan signifikansi dalam partisipasi pembuatan kebijakan di desa, yangmana sangat penting untuk mendukung terpenuhinya kebutuhan perempuan kepala keluarga. Lili Romli (2015) menjelaskan bahwa ada beberapa hambatan bagi perempuan untuk terlibat dan dilibatkan dalam pengambilan keputusan desa; 1) kultur dan prasangka yang menolak partisipasi perempuan dalam kegiatan ekonomi, sosial, dan politik; 2) hambatan-hambatan legal formal; 3) minimnya akses pendidikan perempuan; 4) kualitas kesehatan perempuan yang rendah. Hal ini menjadi satu tantangan bagi perempuan desa untuk menembus batas-batas budaya patriarki yang secara disadari atau tidak, telah membentuk domestikasi perempuan sekaligus meminggirkannya dari ruang publik; akses terhadap ekonomi, pendidikan, dan hak-hak politik.

Hal-hal tersebut menjadi perhatian berbagai organisasi masyarakat sipil yang berfokus pada pemberdayaan perempuan. Beberapa dari mereka bekerja pada level desa, salah satunya Perempuan Kepala Keluarga (PEKKA). Hingga 2019, LSM yang dibentuk tahun 2001 ini telah bekerja di wilayah-wilayah di bawah garis kemiskinan. Mereka melakukan pendampingan di 22 provinsi dan 855 desa di seluruh Indonesia, salah satunya Desa Batangan (PEKKA, 2019). Survei yang mereka lakukan di daerah-daerah itu menunjukkan bahwa dalam setiap empat keluarga, terdapat satu keluarga dikepalai oleh perempuan 
(PEKKA\&SMERU, 2012). Mereka yang rata-rata berusia antara 18-65 tahun dan berpendidikan formal rendah dengan 57\% tercatat buta huruf ini harus menghidupi 1-6 orang anggota keluarga (PEKKA, 2018). Dengan keterbatasan tingkat pendidikan dan modal usaha, sebagian besar dari mereka (90\%) bekerja di sektor-sektor yang hanya mampu menghasilkan pendapatan sangat rendah, yaitu rata-rata $\mathrm{Rp} 10,000 /$ hari. Rentannya kehidupan perempuan kepala keluaga membuat LSM ini melakukan pendampingan dengan berbagai pendekatan, mulai dari membuka sekolah perempuan, melaksanakan program pengadaan dokumen, membuat koperasi simpan-pinjam, melakukan advokasi kebijakan ramah perempuan, dan lain sebagainya.

Artikel ini hendak melihat secara seksama tentang bagaimana LSM ini berstrategi untuk memberdayakan perempuan kepala keluarga di desa. Dengan mengambil studi kasus advokasi mereka di Desa Batangan Kabupaten Bangkalan Jawa Timur, rumusan masalah yang akan dijawab dalam penelitian ini adalah bagaimana strategi advokasi PEKKA dalam memberdayakan perempuan rentan di Desa Batangan?

Artikel ini diharapkan mampu memperkaya referensi kajian ilmu sosial dan politik di Indonesia, khususnya studi mengenai perempuan kepala keluarga di desa. Pun begitu, dalam proses pengambilan data dan analisisnya, penelitian ini memiliki limitasi yang perlu dipaparkan. Poin ini meliputi temuan praktik peminggiran dan strategi advokasi pemberdayaan yang beragam sesuai dengan konteks desa. Secara umum, keterkaitan antara norma dan domestikasi perempuan di level desa memang berbeda dengan perempuan kota. Namun dalam kultur 
dan sejarah masyarakat yang berbeda-beda pula, kondisi perempuan desa juga tidak bisa diseragamkan-terutama ketika dikaitkan dengan norma dan nilai yang dibangun. Norma dan budaya ini pada akhirnya memengaruhi jenis advokasi, pendekatan, program, dan strategi pemberdayaan perempuan. Artikel ini ingin menghadirkan konteks spesifik LSM PEKKA di Desa Batangan sebagai salah satu referensi dalam mengidentifikasikan norma dan nilai spesifik, kebutuhan utama, dan strategi advokasi secara kontekstual.

Penelitian ini menggunakan metode penelitian kualitatif dengan pendekatan studi kasus. Pemilihan metode ini dilakukan untuk melihat lebih jauh pengalaman-pengalaman subjektif-dan intersubjektifsetiap narasumber sehingga mampu menghadirkan analisis yang kontekstual. Creswell (2009) menjelaskan bahwa metode penelitian kualitatif memungkinkan peneliti menghadirkan gambaran-gambaran detail melalui data berbasis pengalaman-pengalaman nyata. Kemudian, studi kasus menurut Sturman (1997) merupakan pendekatan untuk mengeksplor individu, kelompok, atau fenomena-fenomena tertentu. Lebih spesifik, Sagadin (dalam Mohajan, 2018) mengatakan bahwa studi kasus digunakan untuk menganalisis dan menggambarkan beberapa hal, meliputi; (1) aktivitas individu, kebutuhan spesifik, dan sorot kehidupan; (2) permasalahan kelompok dan sejarahnya; atau (3) fenomena-fenomena dalam institusi tertentu. Melalui pendekatan studi kasus, tulisan ini melihat lebih jauh bagaimana perempuan Desa Batangan mengidentifikasikan kebutuhannya di tengah belenggu patriarki di desanya. 
Lebih spesifik, artikel ini juga menempatkan LSM PEKKA sebagai aktor yang hadir untuk menjawab persoalan tantangan belenggu patriarki bagi perempuan, terutama janda, di Desa Batangan. Sistem patriarki menjadi relevan untuk mengantarkan konteks dinamika gender dan politik di Desa Batangan. Pada titik ini, strategi advokasi kemudian menjadi konsep yang didesain secara kontekstual, dalam hal ini untuk melakukan pemberdayaan perempuan di tengah sistem sosial politik yang bekerja.

Pengambilan data primer penelitian dilakukan dengan cara indepth interview, observasi, dan Forum Group Discussion (FGD) dengan perempuan desa sejak Februari hingga Maret 2019. Selain itu, juga dilakukan analisis sejarah hidup tokoh perempuan terkemuka dan analisis cerita perubahan yang terjadi setelah PEKKA hadir. Pemilihan lokasi dan metode penelitian ini disesuaikan dengan rekomendasi lembaga donor yang sedang melakukan kerja sama penelitian bersama PolGov, yakni MAMPU. Nama-nama narasumber yang digunakan juga tidak menggunakan nama asli untuk menjaga privasi narasumber. Sebagai proyek donor, penelitian ini memang tak bisa dilepaskan sepenuhnya dari rekomendasi cakupan dan limitasi kajian dari MAMPU. Artikel ini kemudian menjadi telaah kembali dengan bangunan kerangka konsep yang disesuaikan dengan kondisi di Desa Batangan sekaligus peran LSM PEKKA di dalamnya. 


\section{PATRIARKI DAN STRATEGI ADVOKASI}

Perlu disampaikan di awal, kerangka konsep ini dibangun sebagai upaya membedah strategi LSM PEKKA dalam melakukan pemberdayaan perempuan di tengah praktik peminggiran oleh sistem patriarki yang bekerja. Kaitan antara patriarki dengan strategi advokasi PEKKA dijustifikasi dengan bagaimana desain program LSM disesuaikan dengan identifikasi praktik peminggiran yang kontekstual dan spesifik, dalam hal ini di Desa Batangan. Dengan kata lain, kerangka konsep patriarki dibangun sebagai pengantar atas kondisi desa dan dinamika gender-juga kuasa-yang bekerja di Desa Batangan. Identifikasi praktik dan telaah gambaran ini kemudian dikaitkan dengan susunan strategi LSM PEKKA.

Patriarki dalam hal ini dimaknai sebagai sebuah sistem-sosial, politik, budaya, dan ekonomi-yang secara historis menindas perempuan. Ferguson mengatakan bahwa patriarki sendiri berasal dari istilah rule of the father, dimana laki-laki memegang kekuasaan tertinggi dalam keluarga (Akgul, 2017: 31). Akgul kemudian meminjam studi Butler yang menulis bahwa patriarki diproduksi-dan direproduksidi dalam konstruksi gender yang memengaruhi kepribadian (selfhood) sebagaimana pada akhirnya menghasilkan supremasi laki-laki (Akgul, 2017). Dalam praktiknya, pelanggengan sistem patriarki sangat bergantung pada subordinasi perempuan sebagai fondasi dari kekuasaan laki-laki-yang digambarkan menjadi subjek superior (Walby, 1991). Lebih spesifik, Walby menjelaskan bahwa patriarki adalah sistem yang memungkinkan laki-laki untuk mengontrol dan 
mengeksploitasi perempuan dari aspek produksi, reproduksi, hingga seksualitas.

Beberapa studi mengenai perempuan pedesaan dengan kultur patriarki kuat telah dilakukan di beberapa wilayah. Dalam studi perempuan pedesaan di Pakistan misalnya, dipaparkan bahwa persepsi akan status sosial perempuan di daerah pedesaan-bahkan oleh perempuan itu sendiri-bersifat submisif di bawah kontrol laki-laki (Abbas, Hashim, \& Alzuhairi, 2018). Secara sistemik, hal ini berpengaruh pada status ekonomi perempuan desa yang rendah, minimnya angka lanjut sekolah, dan kondisi kesehatan yang lebih buruk. Pada konteks tersebut, keluarga menjadi salah satu kunci dari sosialisasi nilai-nilai inti sistem patriarki, yaitu peran sosial berbasis gender (Abbas, Hashim, \& Alzuhairi, 2018). Dapat dilihat bahwa subordinasi perempuan kemudian menjauhkan perempuan dari akses pengetahuan dan keterlibatan di ruang publik, membatasi perempuan dengan peran-peran domestik, serta dipinggirkan dari akses terhadap sumber daya.

Permasalahan domestikasi perempuan memunculkan banyak gerakan dan LSM yang berfokus pada pemenuhan hak-hak perempuan. Di ranah perkotaan, hadir gerakan-gerakan, seperti Women's March yang diadakan tiap tahunnya (March, 2020). Muncul juga kemudian LSM yang berfokus pada advokasi pemenuhan hak perempuan di perkotaan. Seperti contoh, hadir Asosiasi Pusat Pengembangan Sumberdaya Wanita (PPSW) yang mempunyai fokus pemberdayaan perempuan strata ekonomi rendah di daerah kumuh perkotaan (PPSW, 
2020). Di level pedesaan, advokasi juga menjadi salah satu koridor menembus ketertindasan perempuan. Munculnya LSM-LSM ini merupakan upaya advokasi hadirnya perubahan dengan fokus strategi yang mengacu pada teori perubahan. Harris (dalam Coffman \& Beer, 2015) mengatakan bahwa teori perubahan adalah ilustrasi bagaimana perubahan yang akan terjadi pada waktu-waktu tertentu dan bagaimana peran organisasi dalam mendorong perubahan tersebut. Sedangkan Serrat (2017) menjelaskan bahwa metode yang digunakan dalam teori perubahan adalah berbasis hasil, pendekatan partisipatif yang menerapkan pemikiran kritis terhadap desain, implementasi, dan evaluasi suatu inisiatif untuk membuat kebijakan, strategi, program, atau proyek secara transformatif. Teori perubahan kemudian berkontribusi menekankan cara berpikir dalam dan berjangka panjang bagi program-program LSM.

Sehubungan dengan itu, Coffman \& Beer (2015) menawarkan kerangka advokasi untuk membuat advokasi strategis yang juga menyerap konsep teori perubahan. Konsep Coffman pada awalnya digunakan decision makers untuk menganalisis kebijakan publik tepat sasaran level pemerintah pusat. Namun, konsep ini dapat juga dipakai untuk menjelasakan langkah startegis LSM menentukan program dan pendekatan. Coffman dan Beer (2015) menulis strategi advokasi sebagai langkah-langkah untuk membuat suatu perubahan. Tulisan ini kemudian memaparkan bahwa dalam merumuskan strategi advokasi yang efektif, penting untuk mengidentifikasikan dan mengaplikasikan teori perubahan. 
Sebelum mengeksplor bangunan konsep strategi advokasi, penting untuk menyampaikan latar belakang pemilihan konsep milik Coffman. LSM PEKKA sendiri memiliki visi untuk melakukan pemberdayaan melalui aspek perubahan. Bangunan konsep Coffman dipilih karena penekanannya pada hasil perubahan yang memperhatikan audiens dengan spektrum-spektrum tertentu di masing-masing aspek. Dengan kata lain, kerangka konsep strategi advokasi ini mencoba mengeksplor lebih jauh aspek perubahan dari strategi PEKKA—dengan melihat kondisi dan konteks sosial politik di Desa Batangan.

Coffman (2008) memaparkan kerangka strategi advokasi yang memperhatikan aspek hasil perubahan (outcomes) dan audiens (audience). Dalam spektrum outcomes, terdapat tiga kategori, yaitu awareness (kesadaran), will (kehendak), dan action (tindakan). Sementara pada spektrum audience, terdapat tiga kategori aktor, meliputi public (publik), influencers (pemengaruh), policy-makers (pembuat kebijakan). Coffman menggambarkan strategi avokasi dalam kerangka sebagai berikut. 


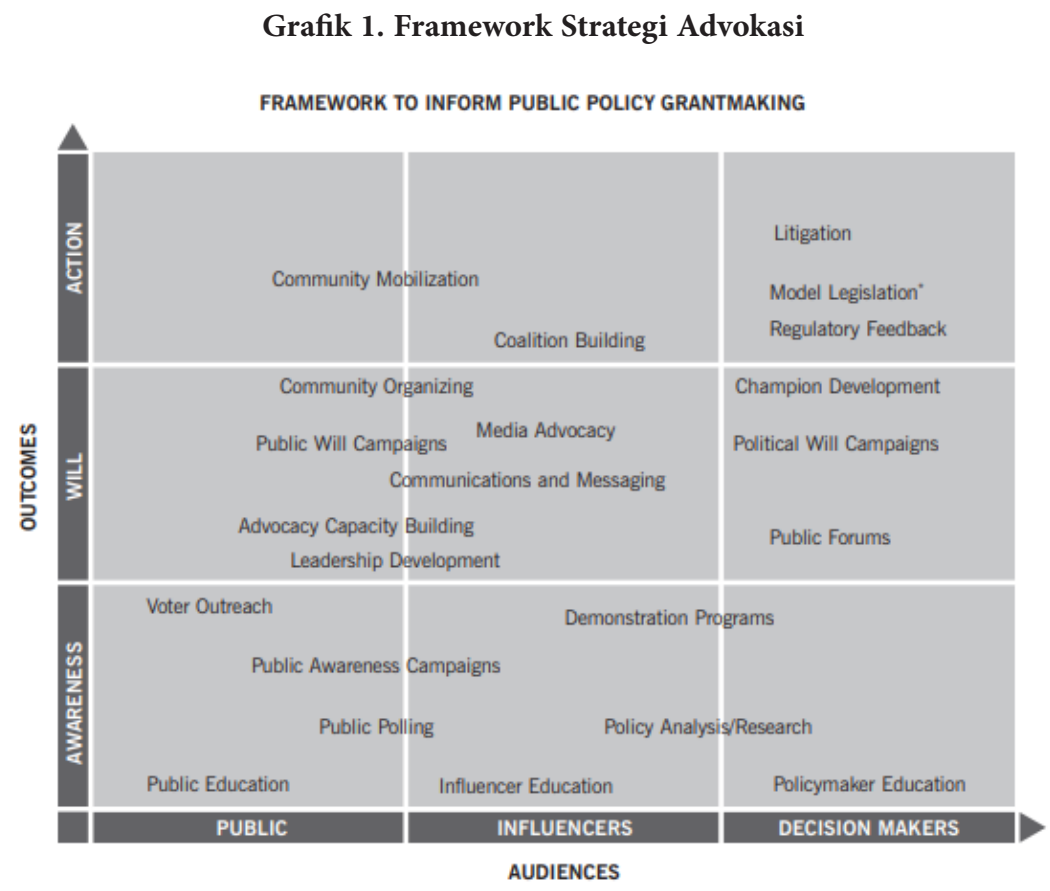

Grafik tersebut dapat membantu organisasi dalam mengidentifikasi strategi advokasinya berdasarkan spektrum dan strategi yang ada. Dalam merumuskan strategi, organisasi tidak harus mengaplikasikan seluruh aktivitas dari setiap spektrum. Di sinilah peran organisasi untuk memetakan setiap spektrum pada konteks masyarakat, dimana perubahan ingin dilakukan. Dengan demikian, aktivitas-aktivitas yang dilakukan sesuai dengan langkah-langkah efektif menuju perubahan sebagaimana menjadi tujuan dari awal. Kerangka yang digunakan Coffman menarik digunakan sebagai acuan analisa dan evaluasi efektivitas LSM PEKKA dalam menentukan strateginya di level desa. 


\section{KONTEKS PATRIARKI DESA BATANGAN}

Desa Batangan merupakan salah satu desa di Kecamatan Tanah Merah Kabupaten Bangakalan. Desa dengan luas wilayah 670.305 hektar ini mempunyai 5.662 penduduk yang seluruhnya beragama Islam dan beretnis Madura. Di bidang pendidikan, selama tahun 2018 data desa mencatat sebanyak 263 orang belum sekolah, 148 orang tidak sekolah, 261 orang tidak lulus SD, 616 orang tamat SD, 328 orang tamat SLTP, 45 orang tamat SLTA, dan 2 orang sarjana. Tingkat pendidikan yang rendah ini mengakibatkan angka pernikahan usia muda (15-20 tahun) di Desa Batangan sangat mudah dijumpai. Dengan kondisi seperti itu, perhatian desa terhadap isu perempuan cenderung masih rendah. Desa masih berfokus pada pembangunan infrastruktur, utamanya jalan. Hal ini disebabkan karena wilayah desa yang sangat luas dan pembangunan belum merata (wawancara Fahrul, Kasi Pemerintahan Desa, 22 Februari 2019).

Ditarik lebih luas, memang anggaran untuk pengarusutamaan gender telah menjadi salah satu prioritas di Jawa Timur melalui sembilan Nawa Bhakti Satya. Implementasi pengarusutamaan ini salah satunya hadir dalam bentuk Anggaran Responsif Gender (ARG). Di tahun 2017, anggaran untuk pengarusutamaan gender sebesar Rp 3,3 Triliun. Di tahun berikutnya, alokasi ini menembus angka Rp 4 Triliun (Dinas PPPA dan Kependudukan Provinsi Jawa Timur, 2019). Dalam penyusunannya, anggaran dan perencanaan responsif gender dilakukan harus berdasarkan analisis gender. Namun, karena pelaksanaan yang masih berjalan top-down, level desa-secara spesifik Desa Batangan- 
tidak memastikan program pengarusutamaan berjalan tepat sasaran dengan persoalan gender.

Sebagaimana disinggung di bagian sebelumnya, dalam perencanaan pembangunan di Desa Batangan, fokus utama pembangunan masih terfokus pada infrastruktur. Penentuan prioritas ini dalam praktiknya mengesampingkan implementasi pemenuhan kebutuhan mendasar, seperti administrasi kependudukan. Banyak anggota masyarakat, termasuk di antaranya perempuan kepala keluarga, masih kesulitan mengurus dokumen kependudukan, seperti KTP, KK, akta kelahiran, dan surat nikah. ${ }^{3}$ Padahal, dokumen-dokumen ini dibutuhkan untuk banyak keperluan, seperti pengadaan surat nikah yang fungsinya untuk memperoleh akta bagi anak yang ingin bersekolah. Absennya analisis gender kontekstual dan komitmen untuk mengidentifikasikan kebutuhan perempuan pada akhirnya menumpuk tantangan dan kesulitan yang dihadapi perempuan Desa Batangan.

Gambaran tentang kesulitan ini misalnya ditunjukkan oleh seorang perempuan desa yang menyandang status janda tanpa pernikahan yang dicatatkan ke negara. Janda tersebut kesulitan mendaftarkan anaknya ke sekolah karena pernikahannya dahulu belum tercatat secara formal. Namun, persoalan ini diselesaikan dengan cara yang kontraproduktif, yaitu menjadikan nama kepala dusun sebagai ayah untuk mendaftarkan sekolah. Hal ini menimbulkan persoalan baru, yaitu tuduhan pemalsuan data.

3 Focus Group Discussion (FGD) dengan perempuan desa tanggal 24 Februari 2019. 
"Ini pengalaman yang paling berat, saya kan pisah sama suami. Kan pas pisah, anak saya masuk sekolah SD. Pas pisah bapak saya mendaftarkan anak saya. Seolah-olah bapak saya ini ya bapaknya anak saya. Padahal kan cucu. Bapak saya kan Pak Sugeng, ya. Terus anak ini namanya Budi. Budi bin Sugeng. Padahal kan kakek, Sugeng itu. Terus akhirnya sama sekolah diminta data akte yang asli. Ya kan saya ndak punya. Ngurus sulit sampe kemana-mana, minta tolong mbak ini, ke Pak Kepala Dusun." (Zara, Janda Desa Batangan, FGD di Desa Batangan, 24 Februari 2019). ${ }^{4}$

Kebutuhan yang dirumuskan tersebut telah menjadi perbincangan warga terutama perempuan. Namun, kebutuhan ini tidak pernah disampaikan pada pemerintah desa, baik secara personal ke Kepala Desa maupun dalam musyawarah desa. Perbincangan kebutuhan perempuan berhenti di ruang-ruang domestik ataupun ruang yang hanya berisi perempuan, seperti posyandu atau muslimat. Rasa malu dan sungkan menjadi tantangan yang dihadapi dalam proses akomodasi kebutuhan perempuan. Perempuan tidak dapat mengekspresikan kebutuhannya kepada Kepala Desa dan perangkatnya. Pada akhirnya, perempuan desa hanya mengikuti rumusan kebutuhan masyarakat berdasarkan perspektif Kepala Desa dan musyawarah desa yang hanya diisi oleh laki-laki. Pengutaraan kebutuhan biasanya dilakukan kepada tokohtokoh desa ketika perempuan desa sudah merasa terdesak; anaknya tidak bisa sekolah, dan sebagainya.

Praktik patriarki di Desa Batangan juga dipengaruhi oleh pola kepimpinan Kepala Desa. Pola kepemimpinan di Desa Batangan masih didominasi oleh tokoh-tokoh laki-laki usia lanjut yang sebenarnya

$4 \quad$ Nama yang digunakan bukan nama sebenarnya 
sudah tidak menduduki jabatan formal pemerintah desa. Struktur pemerintahan desa saat ini mengikuti ketentuan yang ditetapkan oleh pusat, terutama terkait batas minimal pendidikan perangkatnya. Namun, urusan desa dibagi menjadi dua, yakni formal dan informal. Urusan formal dipegang oleh perangkat muda berkaitan dengan administrasi dan tata kelola desa. Sedangkan urusan kemasyarakatan, seperti permasalahan desa, warga masih mendatangi perangkat desa informal (sesepuh desa) untuk dimintai pendapat. Perangkat desa baru hanya menjalani kerja-kerja administratif yang hadir sebagai formalitas belaka. Dengan kata lain, keberlangsungan pemerintahan dan pengambilan keputusan desa masih dikontrol oleh perangkat desa lama, termasuk Kepala Desa.

Kepala Desa Batangan memiliki kuasa cukup besar di Desa Batangan. Ia dihormati karena memiliki hubungan keluarga dengan sejumlah tokoh agama yang dikenal secara lokal dan nasional. Di kabupaten, keturunan Syaichona Moh. Cholil, salah satu tokoh besar NU, dipercaya menjadi pemimpin dan tokoh agama. Di Desa Batangan, Kepala Desa mempunyai hubungan keluarga dengan keturunan Syaichona Moh. Cholil. Ibu tirinya merupakan mantan istri cucu dari Syaichona Moh. Cholil. Selain itu, Kepala Desa juga pernah menjadi murid pesantren Bupati Bangkalan Ra Latif yang juga merupakan keturunan langsung Syaichona Moh. Cholil. Ketokohan ini juga diwariskan ayahnya yang menjabat sebagai Kepala Desa selama 26 tahun dan memegang status sebagai kyai. Ayahnya juga mendirikan sebuah yayasan untuk pengobatan kejiwaan. Yayasan ini dianggap 
sebagai bentuk dari ilmu tinggi yang dimiliki keluarga Kepala Desa. Masyarakat pun sering memanfaatkan jasa mobil ambulans yang dimiliki yayasan ini untuk transportasi ke rumah sakit yang lebih besar. Dengan demikian, masyarakat desa menganggap jasa keluarga Kepala Desa terhadap kehidupan pedesaan besar. Latar belakang Kepala Desa dan konteks agama yang kental di Bangkalan inilah yang menekankan pengaruh kuat Kepala Desa di Desa Batangan.

Hubungan keluarga dengan tokoh-tokoh besar agama menjadikan Kepala Desa orang dengan kuasa kuat di Batangan, termasuk dalam pembuatan keputusan desa. Dalam menjalankan pemerintahan, Kepala Desa tidak pernah mendapatkan resistensi atau penolakan dari masyarakat. Keputusan-keputusan desa dipegang dan dikontrol secara kuat oleh Kepala Desa. Wakil Ketua BPD pun mengatakan bahwa dalam setiap musyawarah desa, baik dari masyarakat maupun dari BPD sendiri tidak pernah berseberangan dengan Kepala Desa (wawancara Mat Suni, Wakil Ketua BPD Desa Batangan, 23 Februari 2019).

Pengaruh Kepala Desa sebagai tokoh kuat tidak kemudian menghasilkan resistansi terbuka terhadap kepentingan perempuan. Di Desa Batangan, sikap Kepala Desa terhadap kelompok atau organisasi perempuan desa tidak resistan, tetapi tidak pula tampak mengakomodasi secara substansial. Sebagai contoh saat ormas maupun LSM perempuan masuk ke desa ini, Kepala Desa maupun perangkatnya tidak tampak mempersoalkan kehadiran mereka. ${ }^{5}$ Namun, Kepala Desa juga tidak

5 Wawancara dengan pengurus Muslimat Desa Batangan tanggal 19 Februari 2019 dan wawancara dengan pengurus PEKKA tanggal 25 Februari 2019. 
kemudian mengakomodir kebutuhan kelompok-kelompok ini. Sebagai contoh, kegiatan-kegiatan Posyandu tidak didanai oleh dana desa namun masih bergantung pada Puskesmas Kecamatan dan dana pribadi bidan desa. Upaya dari pemerintah desa dalam menghadirkan suatu forum untuk menyuarakan kebutuhan perempuan atau melibatkan perempuan dalam musyawarah desa pun cenderung minim. Klaim yang diajukan adalah "informasi dana desa bukan sesuatu yang wajib diketahui perempuan". (wawancara Fahrul, Kasi Pemerintahan Desa Batangan tanggal 22 Februari 2019).

Proses pembuatan keputusan (musyawarah desa) di Desa Batangan masih sangat menunjukkan kultur patriarki yang kental. Musyawarah desa (Musdes) lebih sering dihadiri oleh laki-laki. Petunjuk ini dapat dilihat dari daftar hadir dan foto musyawarah dalam dokumen pelaporan kegiatan desa. ${ }^{6}$ Perempuan desa yang mendapat undangan terbatas pada perangkat desa dan istri perangkat. Tugas perempuanperempuan yang diundang pun hanya berputar pada penyediaan konsumsi (wawancara Fahrul, Kasi Pemerintahan Desa Batangan tanggal 22 Februari 2019). Hal ini cukup ironis mengingat adanya aturan standardisasi ijazah minimal SLTA bagi perangkat yang memunculkan perangkat perempuan, namun peran perangkat perempuan masih terbatas pada peran-peran domestik. Hal ini disebabkan oleh norma sosial di Desa Batangan yang percaya bahwa perempuan hanya

6 Petunjuk berupa foto dapat dilihat di Laporan BUMDes Tahun 2018 dan Monograf Desa Tahun 2018. 
memiliki peran di rumah, bukan di ruang-ruang publik. ${ }^{7}$ Selain itu, musyawarah desa selalu dilakukan pada malam hari, yangmana sangat merugikan pastisipasi perempuan karena norma sosial Desa Batangan yang menjadikan perempuan keluar pada malam hari sebagai hal yang sangat tabu.

\section{STRATEGI ADVOKASI PEKKA DI DESA BATANGAN}

Sejak tahun 2011, perempuan kepala keluarga di Desa Batangan berkesempatan mendapatkan advokasi. Hal ini menyusul masuknya PEKKA, salah satu LSM yang fokus pada pemberdayaan perempuan pedesaan rentan melalui penjaminan hak-hak politik dan ekonomi. LSM yang dibentuk tahun 2001 ini melakukan advokasi untuk perempuan desa yang berstatus kepala keluarga dan janda. Namun pada praktiknya, PEKKA juga memberdayakan perempuan desa selain janda untuk menanamkan nilai-nilai keadilan gender-ketahanan ekonomi, keterlibatan politik, dan pengembangan softskill di komunitas-untuk menghadapi potensi-potensi kerentanan yang ada.

LSM yang memiliki 26 pengurus serikat, 36 kelompok perempuan, dan 1500 kader aktif di Madura ini melakukan aktivitas pemberdayaan dengan cara membuka program sekolah perempuan Akademi Paradigta. Kegiatan ini diadakan sejak tahun 2010 di Center PEKKA ${ }^{8}$ sebagai upaya membentuk kader pertama kali. Program pelatihan ini didesain selama 16 kali pertemuan dan bertujuan untuk mempersiapkan kader

7 Observasi langsung dan Focus Group Discussion (FGD) perempuan desa mengenai peran perempuan dalam pemerintahan desa tanggal 24 Februari 2019.

8 Center PEKKA adalah kantor Serikat PEKKA di Kabupaten. 
supaya memiliki pengetahuan dan kemampuan praktis terlibat dalam urusan publik di desa. Lulusan Akademi Paradigta kemudian menjadi kader PEKKA dan beberapa ditunjuk menjadi pengurus inti serikat atau pengurus kelompok PEKKA di desa.

Program utama PEKKA di level desa selalu mengacu pada program Sekretariat Nasional PEKKA. Di Kabupaten Bangkalan, PEKKA menempatkan pemberdayaan legal (legal empowerment) sebagai prioritas utama program akses terhadap perlindungan sosial. Untuk mengakses program perlindungan sosial tersebut, PEKKA mendorong aksi kolektif perempuan di tingkat akar rumput untuk mengakses layanan dokumen identitas, seperti sertifikat status pernikahan, KK, KTP, dan akte kelahiran. Program ini disebut Klinik Layanan Informasi dan Konsultasi (KLIK). KLIK menjadi program yang menjadi pintu masuk PEKKA di Desa Batangan. KLIK juga bertujuan untuk memberikan layanan informasi mengenai pentingnya identitas kependudukan, pemetaan layanan dokumen kependudukan yang dibutuhkan warga serta perekaman data kependudukan. KLIK di Desa Batangan pada tahun 2016 berhasil mengidentifikasi besarnya kebutuhan warga, baik laki-laki maupun perempuan terhadap surat nikah. Selain itu, KLIK juga menunjukkan kebutuhan masyarakat terkait dokumen, seperti KK, KTP, dan Akte kelahiran. Pelaksanaan KLIK akan ditindaklanjuti dengan proram paralegal lainnya, yaitu fasilitasi pengurusan surat nikah melalui proses pengadilan isbat jalur prodeo (cuma-cuma) bagi masyarakat miskin. Oleh karenanya, PEKKA 
juga menjalin kerja sama dengan Pengadilan Agama Bangkalan serta KUA Kecamatan Tanah Merah.

KLIK mengenai pengurusan surat nikah kemudian diimplementasikan menjadi Peraturan Desa No. 5 Tahun 2018 Tentang Meningkatkan Kutipan Akta Nikah. Desa Batangan merupakan desa pertama di wilayah dampingan PEKKA yang mengeluarkan Perdes tentang penyelenggaraan isbat nikah. Dengan fasilitasi pemerintah desa, sidang isbat nikah diselenggarakan di Kantor Desa sehingga masyarakat desa yang membutuhkan tidak perlu jauh-jauh datang ke Pengadilan Agama di kabupaten. Adanya peraturan desa ini merupakan hasil advokasi serikat PEKKA secara langsung kepada Kepala Desa Batangan. Peraturan desa ini kemudian diklaim menjadi program inisiasi pemerintah desa. PEKKA menjelaskan bahwa klaim pemerintah desa atas program yang diinisianya tidak menjadi masalah pergerakan, justru menjadi indikasi keberhasilan program KLIK. Penanggungjawab Lapangan (PL) PEKKA Bangkalan juga menjelaskan bahwa target KLIK adalah menjadi peraturan desa masing-masing kader sehingga klaim Kepala Desa dirasa tidak menjadi masalah. Di satu sisi, program KLIK cukup memengaruhi kesadaran perempuan desa terhadap pentingnya mengurus dokumen-dokumen kependudukan.

Program dan target PEKKA didesain bertujuan inklusif, menyasar laki-laki dan perempuan. Meski menyandang nama "Pemberdayaan Perempuan Kepala Keluarga", PEKKA di Bangkalan tidak mengkhususkan program kerjanya bagi perempuan kepala keluarga saja. Program paralegal seperti KLIK dan fasilitasi pengurusan surat 
nikah misalnya, melayani warga desa secara umum, baik laki-laki maupun perempuan, terutama dari kalangan keluarga miskin. Selain itu, pembentukan kelompok-kelompok perempuan di wilayah pedesaan juga menargetkan pembentukan kader perempuan secara umum, baik perempuan tidak menikah, kepala keluarga dan ibu tunggal, maupun perempuan bersuami.

Dalam keanggotaan PEKKA, perempuan tidak bersuami akan masuk kategori Anggota PEKKA Biasa, sedangkan bagi yang bersuami masuk kategori Anggota PEKKA Luar Biasa. Pemilihan program KLIK juga didasarkan pada kebutuhan utama perempuan rentan dan "keamanan isu" bagi keberlangsungan organisasi PEKKA di Bangkalan. Isu perlindungan sosial dianggap tidak mengancam bagi struktur kuasa-yang dalam hal ini batas patriarki-karena programnya dapat dimanfaatkan oleh seluruh golongan masyarakat. Dalam konteks masyarakat desa dengan norma adat dan norma keagamaan yang kuat seperti di Desa Batangan, perluasan target keanggotaan PEKKA yang menyasar perempuan secara umum dapat dilihat sebagai bagian dari strategi PEKKA mengatasi stigma buruk tentang perempuan tidak bersuami. Kader PEKKA sering mendapat pertanyaan mengapa organisasi ini menggunakan nama "perempuan kepala keluarga" dan juga sering dianggap akan mempunyai agenda perlawanan terhadap laki-laki-atau suami, yang juga dimaknai sebagai pemimpin.

"Jadi PEKKA itu apa? "Pemberdayaan Perempuan Kepala Keluarga". "Kok perempuan diajarkan menjadi kepala keluarga?” biasa kalau di desa-desa kan seperti itu. "Kok kalian mau mengajarkan ibu-ibu 
menjadi penentang suami-suami mereka" [...] Ada juga yang "Ah kelompoknya janda-janda" kayak gitu. Ada yang pikirannya negatif, "Kelompok janda ya? Perempuan janda ya?" (Pengurus Serikat PEKKA, Wawancara di Kecamatan Tanah Merah, 25 Februari 2019)

\section{PETA ADVOKASI PEKKA DI DESA BATANGAN}

Grafik 2. Peta Strategi Advokasi PEKKA di Desa Batangan

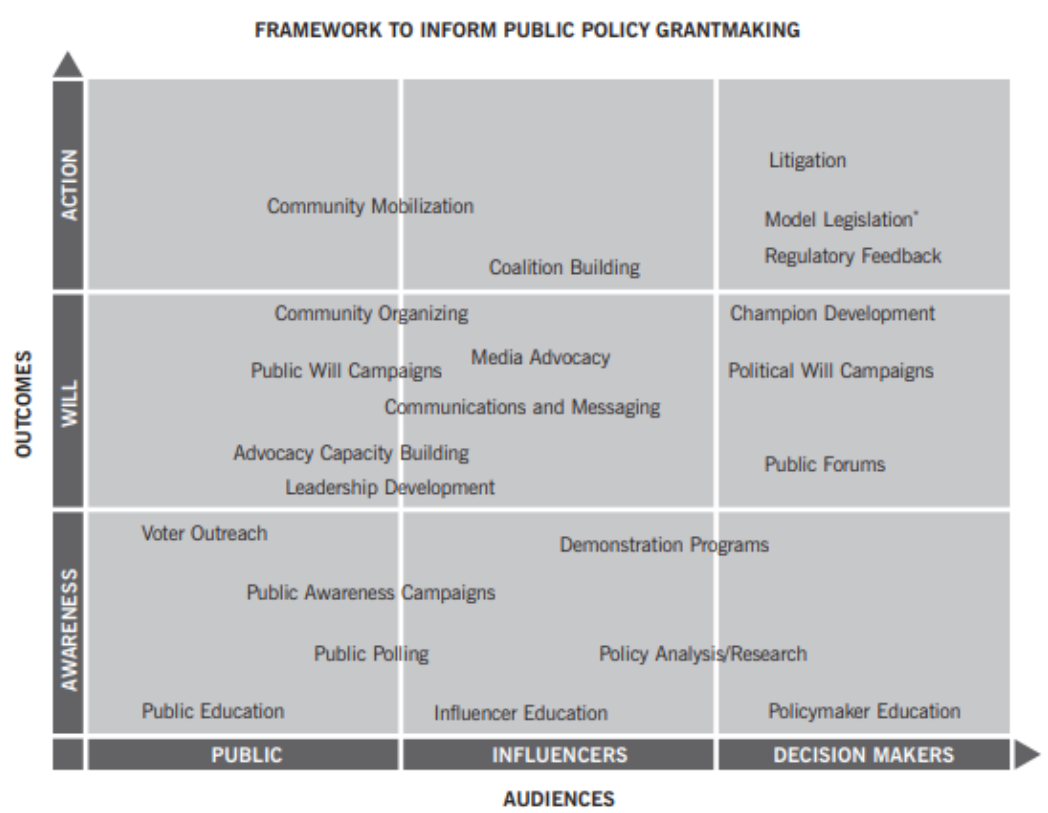

Munculnya stigma buruk mengenai perempuan kepala keluarga terkait dengan situasi kuatnya norma adat dan keagamaan di Bangkalan membuat PEKKA menjadikan program KLIK sebagai program utamanya. Pemilihan program ini dilakukan dengan menggunakan 
pemetaan strategi yang dapat dijabarkan menggunakan konsep Coffman berikut ini.

\section{Mobilisasi Komunitas}

Audiens publik dengan hasil tindakan (action) dalam spektrum yang ditawarkan Coffman menghasilkan strategi mobilisasi komunitas. PEKKA dalam hal ini melakukan mobilisasi komunitas dengan mengidentifikasi kebutuhan utama perempuan desa. PEKKA mengidentifikasi kebutuhan perempuan dan fokus pada kebutuhan utama, yakni pengadaan dokumen kependudukan. Sifat PEKKA yang top-down dalam pemilihan program, dalam artian selalu menjalankan program nasional, membuat program KLIK menjadi program strategis untuk memenuhi kebutuhan perempuan desa. Strategi pemilihan kebutuhan utama ini pun menjadi strategi pergerakan organisasi di tingkat kelompok. Kemudian, kelompok-kelompok yang sudah terbentuk berfungsi untuk membangun jejaring komunitas paralegal atau sebagai perpanjangan tangan program KLIK.

Strategi ini diawali dengan inisiatif kader untuk menginisiasi kelompok perempuan di desanya. Kader biasanya mengawali dengan memetakan kegiatan kolektif perempuan yang sudah berjalan, seperti kelompok ibu-ibu yang menunggu anak sekolah TK atau PAUD, yasinan, atau posyandu. Kader PEKKA akan mendekatkan diri kepada kelompok-kelompok perempuan ini dan menjelaskan mengenai PEKKA serta manfaat yang dapat diperoleh dari menjadi kader PEKKA. Kader PEKKA juga menyasar perempuan desa bersuami atau kader PEKKA 
Luar Biasa. Kader Luar Biasa ini kemudian akan meminta ijin dari suaminya agar bisa berkegiatan. Persetujuan suami merupakan norma yang lazim dipatuhi oleh perempuan di Desa Batangan untuk dapat mengikuti kegiatan di luar rumah. Strategi PEKKA yang menyasar pada kelompok yang sudah berjalan ini dapat dilihat sebagai upaya jangka panjang kaderisasi.

\section{Pengorganisasian Komunitas}

Audiens publik dengan hasil will (kehendak) dalam spektrum yang ditawarkan Coffman selanjutnya menghasilkan strategi pengorganisasian komunitas. Sebagaimana hal tersebut, PEKKA bergerak lewat jaringan kelompok. Kelompok-kelompok ini diarahkan secara langsung oleh serikat PEKKA level kabupaten dan kemudian dipertanggungjawabkan ke sekretaris nasional PEKKA. Dalam menjalankan kelompok, kader aktif akan didorong untuk juga aktif di level serikat dan nasional. PEKKA juga mendorong perempuan rentan untuk mengikuti pelatihan Akademi Paradigta agar dapat menjaring dan memberi manfaat kepada sesama kader di desa atau calon kader.

Pelatihan Akademi Paradigta berisi modul dan serangkaian pengetahuan mengenai gender. Lulusan dari program pelatihan juga didorong untuk menyosialisasikan dan melaksanakan KLIK di desa atau dusunnya. Program ini telah melahirkan dua lulusan dari Desa Batangan yang membantu pengorgansiasian program KLIK di desa ini pada tahun 2016 serta menindaklanjuti hasil KLIK dengan memfasilitasi pengurusan surat nikah melalui sidang isbat jalur prodeo 
di Pengadilan Agama Bangkalan. Perluasan kader dengan Akademi Paradigta ini dapat dimaknai sebagai upaya PEKKA melakukan perubahan pemahaman nilai-nilai diri.

\section{Pembangunan Kapasitas Advokasi dan Kepemimpinan}

Audiens publik dengan hasil will (kehendak) dalam spektrum yang ditawarkan Coffman menghasilkan strategi pembangunan kapasitas untuk melakukan advokasi dan pengembangan kepemimpinan. Lewat pelatihan kepemimpinan Akademi Paradigta, PEKKA membuat jejaring dan menjadi penghubung antarperempuan desa. Dari sini, PEKKA pada akhirnya melebarkan jejaring ke pemerintah desa maupun kabupaten. Kemudian, dalam setiap pertemuan kelompok maupun serikat, kader didorong untuk bisa berbicara di depan umum. Beberapa testimoni kader PEKKA mengungkapkan adanya perubahan dalam diri pasca mengikuti kegiatan kelompok PEKKA. Sebagai tujuan awal, PEKKA mendorong para janda untuk aktif dan tidak merasa lebih "rendah" dari status masyarakat lainnya. PEKKA bekerja di level individu untuk membentuk kader-kader yang berani menembus batasbatas ruang publik.

Dalam strategi Coffman, kehendak yang dimaksud adalah keinginan awal untuk mencoba dan berubah. Pertemuan Akademi Paradigta memberikan gambaran baru mengenai partisipasi dan peran perempuan dalam masyarakat, termasuk di dalamnya perempuan rentan dan janda. Materi Akademi Paradigta juga memuat nilai-nilai keadilan gender sehingga pengetahuan yang dibawa oleh PEKKA 
pada akhirnya harus berbenturan alot dengan budaya patriarki Desa Batangan. Oleh karenanya, PEKKA mengemas pelatihan Akademi Paradigta dengan topik utama pengadaan kebutuhan dokumen legalformal dan pelatihan kepemimpinan.

\section{Pendidikan Publik}

Audiens publik dengan hasil kesadaran (awarness) dalam spektrum yang ditawarkan Coffman juga menghasilkan strategi pendidikan publik. Pendidikan publik yang dibawa LSM selalu beriringan dengan nilai dan semangat perubahan yang menjadi kerangka LSM tersebut. PEKKA dalam hal ini hadir sebagai aktor yang mengubah stigma negatif janda. Bagi kader, pendidikan yang dilakukan PEKKA berupa pengetahuan-pengetahuan dasar mengenai gender dan pemerintahan lewat Akademi Paradigta. Bagi pemerintah setempat, PEKKA berperan sebagai aktor yang membantu pemerintah melaksanakan programnya, yang kemudian dimanifestasikan menjadi Peraturan Desa No. 5 Tahun 2018. Di samping itu, data yang dimiliki PEKKA dapat menjadi sumber data kependudukan yang belum lengkap bagi pemerintah.

\section{Umpan Balik Kebijakan}

Audiens yang menyasar pembuat kebijakan dengan hasil tindakan (action) dalam spektrum yang ditawarkan Coffman selanjutnya menghasilkan strategi umpan balik kebijakan (regulatory feedback). Umpan balik ini diusulkan melalui Surat Keputusan (SK) keterlibatan anggota PEKKA dalam musyawarah. Selain itu, PEKKA 
juga mendorong terbentuknya peraturan desa yang dapat menjamin hak-hak dan kebutuhan perempuan. Di Desa Batangan, PEKKA mengadvokasikan peraturan desa yang kini sudah menjadi Peraturan Desa Batangan No. 5 Tahun 2018 Tentang Meningkatkan Kutipan Akta Nikah. Peraturan desa ini merupakan hasil usulan dan perpajangan program KLIK PEKKA. Program KLIK mendapat sambutan baik dari pemerintah desa karena beberapa alasan, yaitu pertama, dianggap tidak mengganggu kepentingan kekuasaan politik (tidak mengancam struktur kuasa). Kedua, sejalan dengan program pelayanan hukum yang bertujuan menjangkau masyarakat miskin. ${ }^{9}$ Dengan demikian, KLIK tidak mendapat resistensi dari Kepala Desa karena dianggap sebagai program yang "ramah" terhadap semua golongan. Perdes ini kemudian mendapat alokasi Anggaran Dana Desa (ADD) tahun 2017 dan 2018. Namun, sebagai kompromi hadirnya PEKKA di desa, Kepala Desa Batangan mengklaim Perdes tersebut sebagai program inisiatif pemerintah desa. Konteks desa yang kental budaya patriarki membuat isu pelegalan dokumen kepundudukan dianggap sebagai isu yang strategis.

Selain itu, penjaringan kader dilakukan dengan memanfaatkan ketokohan Kepala Desa. Melihat pengaruh kuat yang dimiliki Kepala Desa, strategi awal PEKKA di Desa Batangan adalah dengan memberikan bukti nyata pendatatan dokumen identitas. Strategi ini dirasa efektif untuk mendapatkan simpati dan dukungan dari tokoh

9 Program ini merupakan program dari Mahkamah Agung. Wawancara Hakim Mahkamah Agung Bangkalan tanggal 18 Februari 2019. 
masyarakat terhadap program PEKKA, sekaligus menjadi modal utama untuk meyakinkan warga desa. Pembuktian data dan dokumen ini juga dapat dilihat sebagai upaya mempertahankan posisi PEKKA di Desa Batangan. Dengan demikian, penjaringan kader dan terbentuknya kelompok di setiap dusun meluas.

\section{Litigasi}

Audiens pembuat kebijakan dengan hasil tindakan (action) dalam spektrum yang ditawarkan Coffman menghasilkan strategi litigasi. Litigasi dilakukan untuk meminimalisir dampak negatif sakaligus mengoptimalkan program LSM lewat instrumen-instrumen yang ada. Dalam rangka litigasi, PEKKA melakukan kerja sama dengan pemerintah desa dan daerah. Di Bangkalan, PEKKA menjalin kerja sama (MoU) dengan Pengadilan Agama Bangkalan sejak tahun 2011 untuk mengakses sidang isbat keliling dan sidang isbat jalur prodeo (program layanan cuma-cuma dari Mahkamah Agung untuk masyarakat miskin). PEKKA dalam hal ini menjadi penghubung antara Pengadilan Agama dengan masyarakat yang terkendala akses. Menurut Hakim Pengadilan Agama, data-data dari LSM seperti PEKKA memang sangat dibutuhkan karena Pengadilan Agama maupun Dinas Kependudukan dan Pencatatan Sipil kesulitan mengakses seluruh desa. Sementara bagi PEKKA, Pengadilan Agama memiliki instrumen yang dapat mendukung keberlangsungan program PEKKA. Selain itu, dalam lima tahun terakhir, PEKKA juga bekerja sama dengan Dinas Kependudukan dan Catatan Sipil (Disdukcapil) Kabupaten Bangkalan 
dalam mengurus dokumen identitas KK, KTP, dan Akte. Disdukcapil menandatangani surat kerja sama (MoU) untuk menerima semua permohonan dokumen identitas yang diajukan oleh PEKKA pada tahun 2015. Namun, tidak seperti Pengadilan Agama, kerja sama ini belum dapat menghadirkan layanan keliling Disdukcapil ke tingkat desa di Bangkalan.

Di Desa Batangan, upaya litigasi PEKKA dapat dilihat dari strategi awal masuk ke desa. PEKKA masuk ke Desa Batangan melalui pendekatan struktural. Dalam artian, kader awal PEKKA merupakan perempuan yang berada di lingkar jaringan Kepala Desa. Hal ini dapat dilihat dari pengurus inti kelompok adalah istri kades atau kadus setempat. Pengurus kelompok juga merupakan saudara atau anak dari perempuan-perempuan desa yang cukup terpandang. Untuk itu, sebagai langkah awal, PEKKA menjalin hubungan baik dengan Kepala Desa. Hubungan baik antara PEKKA dan pemerintah desa ditunjukkan dengan adanya program isbat nikah yang kemudian menjadi peraturan desa seperti yang sudah disinggung sebelumnya.

"[...] Biasanya kalau kita lewat ke desa kan kepala desa, kepala desa itu nunjuk kadus ini. Nanti kadus itu yang akan "Oh ini orangnya yang aktif", akhirnya Kadus yang (menunjukkan) "Ini mbak bisa dijadikan kader". Kadang ya kita melalui teman juga. Dari mulut ke mulut, maksudnya dari kenalan satu ke yang lain. [...] (tapi) mesti dari Kades. Ini kalau setiap kegiatan kalau ngga memberitahu Kades, berbahaya. Kelompok bisa dibubarkan." (Ketua Serikat PEKKA, Wawancara di Kecamatan Tanah Merah, 25 Februari 2019). 


\section{KESIMPULAN}

Pembahasan mengenai bagaimana konsep patriarki bekerja di pedesaan, berdasarkan temuan dalam penelitian ini, berfokus pada minimnya akses terhadap partisipasi politik dan redistribusi sumber daya ekonomi, serta kondisi sosial-budaya yang membatasi kehidupan sosial perempuan desa. Secara garis besar, temuan di Desa Batangan memperlihatkan bagaimana partisipasi politik perempuan desa dibatasi dan cenderung dipinggirkan dari skala prioritas arah pembangunan desa. Di Desa Batangan, persoalan perempuan selain minimnya ruang partisipasi politik adalah konteks sosiokultural, dimana nilainilai patriarki bekerja dalam pelanggengan budaya jam malam bagi perempuan dan pembedaan kerja berdasarkan gender-produksipublik (laki-laki) dan reproduksi-domestik (perempuan). Hal ini juga menunjukkan urgensi keterlibatan pihak luar, dalam hal ini LSM, sebagai aktor penggerak advokasi.

Melihat persoalan perempuan desa, terutama perempuan desa yang rentan-janda, advokasi dan rumusan strateginya menjadi salah satu koridor pemberdayaan perempuan. Berdasarkan temuan dan pembahasan di bagian sebelumnya, dapat disimpulkan bahwa strategi advokasi pemberdayaan dibagi menjadi dua strategi utama, yaitu strategi pemilihan isu dan strategi jejaring aktor. Strategi pemilihan isu disesuaikan dengan kebutuhan utama perempuan desa. Merespons hal ini, strategi advokasi di level akar rumput dihadirkan melalui basis material konteks desa. Di Desa Batangan, perlindungan sosial menjadi persoalan utama perempuan desa. Berdasarkan pemetaan tersebut, 
isu strategis ini kemudian diterjemahkan dalam bentuk rangkaian program advokasi KLIK bagi pihak-pihak terkait. Dari hasil analisis strategi advokasi pemilihan isu utama, perempuan yang membentuk komunitas, dalam hal ini PEKKA, dapat secara sistemik melakukan pergerakan. Gerakan perempuan desa dibentuk sedemikian rupa agar terkesan tidak terlalu agresif. Di Batangan, kultul patron-klien masih sangat kental dirasakan. Oleh karenanya, isu yang diangkat adalah isu perlindungan sosial karena dianggap "tidak mengganggu" struktur kuasa Kepala Desa.

Sementara dalam strategi jejaring aktor, konteks Desa Batangan memunculkan temuan bahwa proses pemberdayaan perempuan sangat bergantung pada tokoh-tokoh perempuan yang berpengaruh di desa dan mempunyai hubungan dengan Kepala Desa. Tingkat kepercayaan yang hadir mengiringi penokohan ini mampu memperkuat bargaining dari perempuan sebagai subjek pembangunan di desa. Berdasarkan temuantemuan dalam tulisan ini, tokoh-tokoh perempuan berpengaruh di desa memungkinkan terjadinya redistribusi sumber daya sosial, politik, dan ekonomi sebagai bentuk proses pemberdayaan. Identifikasi terhadap aktor-aktor ini dilakukan melalui pemetaan tokoh-tokoh berpengaruh di masyarakat, baik formal maupun informal. Tokoh-tokoh ini yang kemudian memengaruhi pemberdayaan perempuan sekaligus menjadi jalan pembuka bagi program-program PEKKA. Oleh karenanya, strategi awal PEKKA setiap desa adalah penjaringan kader di lingkar kuasa desa dan Kepala Desa. Strategi ini efektif digunakan karena kepercayaan masyarakat yang tinggi kepada Kepala Desa. 
Selain dua strategi utama, penelitian ini menganalisis adanya strategi melalui jalur pembuatan kebijakan dalam rangka upaya litigasi. PEKKA sebagai advokat mengupayakan pendekatan institusional untuk menjamin pelaksanaan program di masa mendatang, misalnya melalui penandatanganan kerja sama (MoU) dan Perdes. PEKKA di Bangkalan sudah menjalin kerja sama institusional dengan Pengadilan Agama dan Disdukcapil Kabupaten Bangkalan. Sementara di tingkat desa, Perdes yang sudah berhasil ditetapkan adalah di Desa Batangan tahun 2017 dan 2018 tentang penyelenggaraan sidang isbat nikah yang dibiayai APBDes. Perdes ini menjadi klaim pemerintah setempat atas keberhasilan pemerintah dalam memberdayakan perempuan. Klaim pemerintah ini merupakan bentuk kompromi PEKKA agar pemberdayaan perempuan tetap bisa dijalankan.

Pada akhirnya, pemberdayaan perempuan yang menghasilkan perubahan nilai keadilan gender di level desa masih efektif dilakukan pihak eksternal. PEKKA, sebagai advokat sekaligus komunitas bagi perempuan berkumpul, hadir sebagai wadah perempuan miskin desa mengklaim hak-hak politik, ekonomi, dan sosialnya. PEKKA juga hadir sebagai wadah merebut ruang publik yang dibentuk atas dasar sistem patriarki struktural. Basis material desa juga mendukung meningkatnya partisipasi perempuan di desa yang juga berfokus pada perempuan rentan sebagai aktor penyelanggara.

Dasi hasil penelitian tersebut, beberapa kendala advokasi masih kerap ditemui. Pertama, aktivitas serikat PEKKA banyak menjadi tantangan personal bagi kader-kader muda yang akan menikah. Meski 
secara kelembagaan PEKKA tidak membatasi keanggotaan hanya pada perempuan kepala keluarga, aktivitas pengorganisasian dan advokasi yang dilakukan PEKKA memerlukan alokasi waktu yang cukup banyak sehingga bagi perempuan yang memiliki suami membutuhkan negosiasi lebih lanjut dengan keluarganya. Kedua, sumber daya manusia untuk menjadi PL PEKKA sangat terbatas. Banyak PL yang mengundurkan diri pada tahun 2016 membuat kerja-kerja PL di beberapa daerah kurang optimal. Hal ini juga disebabkan keharusan PL berada di dua lokasi yang hampir bersamaan. Ketiga, keterbatasan bahasa membuat advokasi gerakan terhambat. Manfaat PEKKA hanya dirasakan oleh beberapa orang yang memahami Bahasa Indonesia dengan baik. Kegiatan advokasi pun terkadang harus dilakukan secara top-down dan berputar pada aktor-aktor tertentu. Keempat, meski PEKKA menjalankan program sesuai dengan konteks desa masingmasing, nyatanya program PEKKA masih mengikuti program nasional tanpa benar-benar melakukan survei desa. Hal ini menimbulkan gap pengetahuan dasar yang cukup besar antara aktivis PEKKA dengan perempuan desa lainnya.

Dalam menjalankan strategi, LSM PEKKA menyerap teori perubahan yang berbasis pada hasil. Metode yang digunakan LSM dalam menetapkan strategi kemudian juga melihat konteks desa sebagai faktor pendukung program. Melihat kuatnya norma dan budaya patriarki desa, PEKKA melakukan pendekatan implisit lewat jaringan kepala desa. Relasi kuasa yang begitu kuat di Desa Batangan membuat LSM, seperti PEKKA harus berkompromi dengan klaim atas program. 
LSM juga pada akhirnya memanfaatkan jaringan kuasa tersebut untuk mendapat dukungan secara sosial dalam upaya pemberdayaan perempuan. Dengan segala keterbatasan, akhirnya strategi advokasi PEKKA secara garis besar dapat dilihat sebagai salah satu strategi LSM yang berusaha berkompromi dan beradaptasi sesuai norma yang ada dalam masyarakat secara spesifik di masing-masing desa. 


\section{REFERENSI}

Abbas, S., Hashim, M., \& Alzuhairi, A. A. (2018). Status of Rural Women: Patriarchy and Inevitability of Subjugation: A Study of Rural Area in Multan, Pakistan. Journal of Education and Practice, 107-114.

Akgul, F. (2017). Patriarchal Theory Reconsidered: Torture and GenderBased Violence in Turkey. London: Palgrave Macmillan.

Bachri, B. S. (2010). Meyakinkan Validitas Data melalui Triangulasi pada Penelitian Kualitatif. Jurnal Teknologi Pendidikan, Vol. 10. No. 1, 46-62.

Badan Pusat Statistik. (2019). Persentase Penduduk 10 Tahun Ke Atas yang Tidak/Belum Pernah Sekolah menurut Provinsi, Daerah Tempat Tinggal, dan Jenis Kelamin, 2009-2018. Jakarta: Badan Pusat Statistik.

Badan Pusat Statistik. (2019). Persentase Penduduk Berumur 10 tahun Ke atas yang Buta Huruf menurut Provinsi dan Jenis Kelamin, 2009-2018. Jakarta: Badan Pusat Statistik.

Badan Pusat Statistik. (2019). Persentase Rumah Tangga menurut Provinsi, Jenis Kelamin KRT yang Bekerja, dan Daerah Tempat Tinggal, 2009-2018. Jakarta: Badan Pusat Statistik. 
BPS. (2019, November 20). Badan Pusat Statistik Kabupaten Hulu Sungai Utara. Indeks Pembangunan Manusia pada 2019. Retrieved from https:// hulusungaiutarakab.bps.go.id/subject/26/ indeks-pembangunan-manusia.html.

BPS. (2019, November 21). BPS Kabupaten Bangkalan. Indeks Pembangunan Manusia pada 2019. Retrieved from https://bangkalankab.bps.go.id/ publication/2019/09/30/62ae4bcec8e31e6d2847c3b2/ kecamatan-bangkalan-dalam-angka-2019.html.

Coffman, J. (2008). Foundations and Public Policy Grantmaking. San Fransisco: The James Irvine Foundation .

Coffman, J., \& Beer, T. (2015). The Advocacy Strategy Framework: A Tool for Articulating an Advocacy. Washington: Center for Evaluation Innovation.

Colfer, C. J., Achdiawan, R., Roshetko, J. M., Mulyoutami, E., Yuliani, E. L., Mulyana, A., . . . Erni. (2015). The Balance of Power in Household Decision-Making: Encouraging News on Gender in Southern Sulawesi. World Development, 147-164.

Creswell, J. W. (2009). Research Design: Qualitative, Quantitative, and Mixed Method Approaches. Los Angeles: SAGE Publications. 
Dinas Pemberdayaan Perempuan, Perlindungan Anak, dan Kependudukan Provinsi Jawa Timur. (2019). Implementasi Pengarusutamaan Gender (PUG) Melalui PRRG di Jawa Timur. Surabaya: Dinas Pemberdayaan Perempuan, Perlindungan Anak, dan Kependudukan Provinsi Jawa Timur.

Hanzl, S., Meschik, M., \& Sammer, G. (2003). Policy Formulation and Implementation. PORTAL Written Material.

Laksono, A. D. (2015). Pengumpulan Data Penelitian Kualitatif. In A. D. Laksono, Penelitian Kualitatif di Bidang Kesehatan, (pp. 15$34)$.

March, W. (2020, June 14). Women's March: Home. Women's March pada 2020. Retrieved from https://womensmarch.com/.

Mies, M. (1986). Patriarchy and Accumulation On A World Scale: Women in the International Division of Labour. London: Zed Books.

Migunani. (2017). Women Collective Action for Empowerment in Indonesia, A Study of Collective Action Initiated by Partners of the MAMPU Program. Yogyakarta: Migunani and MAMPU.

Mohajan, H. (2018). Qualitative Research Methodology in Social Sciences and Related Subjects. Munich: Munich Personal RePEc Archive.

Murray, M. (2005). The Law of the Father? Patriarchy in the Transition from Feudalism to Capitalism. London: Taylor \& Francis. 
PEKKA. (2018, January 13). Tentang Kami: Latar Belakang. Pemberdayaan Perempuan Kepala Keluarga Women Headed Family Empowerment pada 2018. Retrieved from https://pekka. or.id/latar-belakang/.

PEKKA. (2019). Laporan Tahunan Yayasan PEKKA. Jakarta: Perempuan Kepala Keluarga.

Pekka. (2020, January 13). Kerangka Pemberdayaan Pekka. Pemberdayaan Perempuan Kepala Keluarga pada 2020. Retrieved from https://PEKKA.or.id/kerangka-pemberdayaan.

Pekka. (2020, January 13). Latar Belakang. Pemberdayaan Perempuan Kepala Keluarga pada 2020. Retrieved from https://pekka.or.id/ latar-belakang/.

Pekka. (2020, January 13). Program Kami. Pemberdayaan Perempuan Kepala Keluarga pada 2020. Retrieved from https://pekka.or.id/ ekonomi-dan-penghidupan-berkelanjutan/.

PEKKA\&SMERU. (2012). Survei Sistem Pemantauan Kesejahteraan Berbasis Komunitas (SPKBK). Jakarta: The SMERU Research Institute.

PPSW. (2020, June 14). PPSW: Tentang Kami. Asosiasi PPSW pada 2020. Retrieved from https://ppsw.or.id/index.php/tentanasosiasi-ppsw/.

Prugl, E. (1996). Home-Based Workers: A Comparative Exploration of Mies's Theory of Housewifization. Frontiers, 114-135. 
Rogers, B. (1980). The Domestication of Women: Discrimination in Developing Societies. London: Kogan Page.

Romli, L. (2015, December). Pengakuan dan Penguatan Peran Perempuan dalam Implementasi UU Desa Nomor 6 Tahun 2014. Pusat Kajian Politik Universitas Indonesia pada 2015. Retrieved from https://www. puskapol.ui.ac.id/wp-content/uploads/2015/12/ Perempuan-dan-Desa-Lili-Romli-Kemendes-11.pdf.

Serrat, O. (2017). Theories of Change. In: Knowledge Solutions. In O. Serrat, Knowledge Solutions: Tools, Methods, and Approaches to Drive Organizational Performance (pp. 237-243). Singapore: Springer.

Sturman, A. (1997). Case Study Methods. In J. P. Keeves (Ed.), Educational Research, Methodology and Measurement: An International Handbook (pp. 61-66). Oxford: Pergamon.

Walby, S. (1991). Theorizing Patriarchy. New Jersey: John Wiley \& Sons.

Zulminarni, N. (2013). Melawan Pasrah. Jakarta: Pemberdayaan Perempuan Kepala Keluarga.

Zulminarni, N. (2016). Laporan Akhir Tahun Pemberdayaan Perempuan Kepala Keluarga. Jakarta: Yayasan Pemberdayaan Perempuan Kepala Keluarga.

\section{WAWANCARA}

Fahmi, N. (2019, Maret 3). Life History. (A. Imelda, Interviewer) 
Fahrul. (2019, Februari 22). Pembagian Kebutuhan Desa. (A. Imelda, Interviewer)

Hayati, H. (2019, Februari 20). Pengaruh Muslimat. (A. Imelda, Interviewer)

Hazanah. (2019, Februari 21). Sumber Air Bersih. (A. Imelda, Interviewer)

Hernadi, F. (2019, Juli 11). Struktur Pemerintahan Desa . (A. Imelda, Interviewer)

Hidayatullah. (2019, Juli 16). Pemerintahan Desa. (A. Imelda, Interviewer)

Khaerani. (2019, Juli 18). Sejarah Desa Tambalang Tengah. (A. Imelda, Interviewer)

Lestary, D. (2019, Juli 11). Konteks Perempuan Desa. (A. Imelda, Interviewer)

Mat Suni. (2019, Februari 23). Wakil BPD Desa Batangan. (A. Imelda, Interviewer)

Rianingsih, M. (2019, Oktober 4). Bendahara PEKKA. (A. Imelda, Interviewer)

Rianingsih, M. (2019, Oktober 4). Pembiayaan PEKKA. (A. Imelda, Interviewer)

Toyibah. (2019, Februari 27). Pengelolaan BUMDes. (A. Imelda, Interviewer) 